\title{
FISH DISTRIBUTIONS AND NUTRIENT CYCLING IN STREAMS: CAN FISH CREATE BIOGEOCHEMICAL HOTSPOTS?
}

\author{
Peter B. McIntyre, ${ }^{1,2,7}$ Alexander S. Flecker, ${ }^{1}$ Michael J. Vanni, ${ }^{3}$ James M. Hood, ${ }^{4}$ Brad W. Taylor ${ }^{5}$ \\ and Steven A. Thomas ${ }^{6}$ \\ ${ }^{1}$ Department of Ecology and Evolutionary Biology, Cornell University, Ithaca, New York 14853 USA \\ ${ }^{2}$ School of Natural Resources and Environment, University of Michigan, Ann Arbor, Michigan 48103 USA \\ ${ }^{3}$ Department of Zoology, Miami University, Oxford, Ohio 45056 USA \\ ${ }^{4}$ Department of Ecology, Evolution, and Behavior, University of Minnesota, St. Paul, Minnesota 55108 USA \\ ${ }^{5}$ Department of Biological Sciences, Dartmouth College, Hanover, New Hampshire 03755 USA \\ ${ }^{6}$ School of Natural Resources, University of Nebraska, Lincoln, Nebraska 68583 USA
}

\begin{abstract}
Rates of biogeochemical processes often vary widely in space and time, and characterizing this variation is critical for understanding ecosystem functioning. In streams, spatial hotspots of nutrient transformations are generally attributed to physical and microbial processes. Here we examine the potential for heterogeneous distributions of fish to generate hotspots of nutrient recycling. We measured nitrogen $(\mathrm{N})$ and phosphorus $(\mathrm{P})$ excretion rates of 47 species of fish in an N-limited Neotropical stream, and we combined these data with population densities in each of 49 stream channel units to estimate unit- and reach-scale nutrient recycling. Species varied widely in rates of $\mathrm{N}$ and $\mathrm{P}$ excretion as well as excreted N:P ratios (6-176 molar). At the reach scale, fish excretion could meet $>75 \%$ of ecosystem demand for dissolved inorganic $\mathrm{N}$ and turn over the ambient $\mathrm{NH}_{4}$ pool in $<0.3 \mathrm{~km}$. Areal $\mathrm{N}$ excretion estimates varied 47 -fold among channel units, suggesting that fish distributions could influence local $\mathrm{N}$ availability. $\mathrm{P}$ excretion rates varied 14 -fold among units but were low relative to ambient concentrations. Spatial variation in aggregate nutrient excretion by fish reflected the effects of habitat characteristics (depth, water velocity) on community structure (body size, density, species composition), and the preference of large-bodied species for deep runs was particularly important. We conclude that the spatial distribution of fish could indeed create hotspots of nutrient recycling during the dry season in this species-rich tropical stream. The prevalence of patchy distributions of stream fish and invertebrates suggests that hotspots of consumer nutrient recycling may often occur in stream ecosystems.
\end{abstract}

Key words: biodiversity; consumer nutrient recycling; ecological stoichiometry; ecosystem functioning; ecosystem processes; Prochilodus mariae; spatial heterogeneity; tropical fish.

\section{INTRODUCTION}

Rates of biogeochemical reactions vary widely within landscapes, and hotspots of activity are often associated with major physical or chemical transitions (McClain et al. 2003). For instance, aquatic-terrestrial and sediment-water interfaces have long been recognized as critical sites for carbon and nutrient cycling due to exchanges of reactive materials and abrupt shifts in redox conditions (Wetzel 1990). Determining the location, extent, and influence of such hotspots is requisite to understanding biogeochemical cycles at larger scales.

The influence of physical and chemical factors on microbial activities has been emphasized in most studies of biogeochemical hotspots; however, plants and animals can also be important in generating spatial

Manuscript received 20 September 2007; revised 3 December 2007; accepted 11 December 2007. Corresponding Editor: H. Hillebrand.

${ }^{7}$ Present address: School of Natural Resources and Environment, University of Michigan, Ann Arbor, Michigan 48103 USA. E-mail: pbmcinty@umich.edu heterogeneity (McClain et al. 2003). For instance, patches of aquatic plants can facilitate denitrification by altering water movement, light penetration, and substrate availability relative to the surrounding waters (Caraco and Cole 2002). Similarly, variation in invertebrate densities among tide pools creates differences in nutrient recycling rates, thereby affecting algal primary productivity (Bracken 2004). At the landscape scale, mobile animals often create patches of high nutrient cycling rates by focusing their consumption and waste deposition in particular areas. Notable examples include bird rookeries and ungulate grazing lawns (reviewed in McClain et al. 2003).

Two conditions are required for organisms to establish or contribute to biogeochemical hotspots (McClain et al. 2003). First, their role in mediating reaction rates must be significant at local or larger spatial scales. Second, their densities must be sufficiently variable to create spatial heterogeneity in reaction rates. Here we focus upon stream fish, which have the potential to meet both criteria with regard to nutrient cycling. 
Fish play important roles in nutrient cycling in many aquatic ecosystems (Vanni 2002). For instance, direct measurements of nutrient excretion (e.g., Andre et al. 2003), enclosure experiments (e.g., Attayde and Hansson 2001), bioenergetic models (e.g., Kraft 1993), and paleolimnological analyses (e.g., Schindler et al. 2001) indicate that fish can significantly affect nutrient availability and primary productivity. However, the contributions of invertebrates and microbes to nutrient recycling greatly exceeded those of fish in some ecosystems (e.g., Nakashima and Leggett 1980, Grimm 1988, Hudson et al. 1999), and the factors that determine the relative role of fish remain uncertain.

In ecosystems where nutrient recycling by fish constitutes an important flux, their behavior suggests that fish could create spatial hotspots of nutrient recycling in several ways. Species-specific preferences often create differences in fish community structure and biomass among major habitat types (Angermeier and Karr 1983, Schlosser 1987). Similarly, congregations around physical structures or particular microhabitats produce heterogeneous distributions within habitats (e.g., Wright and Flecker 2004). In addition, breeding and feeding migrations of fish often result in longdistance transport of nutrients (Vanni 2002), and schooling behaviors concentrate nutrient release into a limited area (e.g., Meyer et al. 1983).

In this paper we assess whether heterogeneous fish distributions could create hotspots of nutrient cycling in streams. Nutrient concentrations in streams can vary substantially across short distances (e.g., Dent and Grimm 1999, Dent et al. 2001, Lovell et al. 2001), and biogeochemists have generally construed these patterns as the product of surface-subsurface hydrological exchanges and spatial variation in microbial and algal activity (reviewed by Fisher et al. 1998, Malard et al. 2002). This interpretation reflects a belief that physical forcing and microbial processes are the dominant controls on stream nutrient cycling (Naiman et al. 2000). There is also evidence that animals play important roles in nutrient cycling in streams (e.g., Steinman et al. 1995, Vanni et al. 2002, Hall et al. 2003); however, spatial heterogeneity in their influence on nutrient cycling has been considered only in cases of massive habitat alteration (e.g., beavers; Naiman et al. 2000) or mass-mortality (e.g., salmon; Helfield and Naiman 2001).

We studied a midsized Neotropical stream where previous work suggested that fish play an important role in nutrient recycling (Vanni et al. 2002). Benthic primary productivity in this ecosystem is moderately high (Taylor et al. 2006), despite strong limitation of algal growth by nitrogen (N) availability (Flecker et al. 2002). Fish are abundant and diverse, and their dietary breadth allows them access to a large proportion of ecosystem nutrients (Winemiller 1990, Taphorn 1992). Individual fish species vary widely in excretion rates of $\mathrm{N}$ and phosphorus $(\mathrm{P})$ due to phylogenetic constraints on body stoichiometry (Vanni et al. 2002), indicating that community composition could strongly influence aggregate nutrient excretion (McIntyre et al. 2007).

Building upon those results, our goal was to determine whether spatial heterogeneity in fish distributions could produce hotspots of nutrient recycling. To estimate aggregate $\mathrm{N}$ and $\mathrm{P}$ recycling by the entire fish community, we expanded upon an initial survey of excretion rates (Vanni et al. 2002) to include every common fish species and representatives of all trophic and phylogenetic groups. Broad coverage of the fauna is critical because nutrient excretion rates are determined by a combination of dietary nutrient content, body nutrient content, and growth rates (Schindler and Eby 1997, Sterner and Elser 2002), each of which may vary among species. Per capita excretion rates were combined with the results of an extensive fish census to calculate aggregate excretion rates and $\mathrm{N}: \mathrm{P}$ ratio. To investigate the importance of nutrient excretion by fish at the ecosystem level, we compared aggregate excretion rates to measured rates of ecosystem $\mathrm{N}$ uptake and ambient nutrient concentrations.

The spatial resolution of our fish abundance data allowed us to estimate the magnitude of variation in aggregate excretion among stream channel units. To assess the factors responsible for spatial patterns in nutrient recycling, we tested the relationship between aggregate excretion estimates and fish community structure, habitat type, and habitat characteristics. These analyses represent the first quantification of spatial heterogeneity in nutrient recycling by stream animals and suggest that naturally heterogeneous distributions of fish could give rise to biogeochemical hotspots in this species-rich ecosystem.

\section{Materials And Methods}

The study was conducted during the dry season (January-March 2004) in Rio Las Marias, a fourthorder stream in the Andean piedmont of Venezuela $\left(9^{\circ} 10^{\prime} \mathrm{N}, 69^{\circ} 44^{\prime} \mathrm{W}\right)$. We adopted the methods of Vanni et al. (2002) for measuring nutrient excretion. Fish were collected between 9:00 and 17:00 using primarily seine and cast nets. When necessary, we also used a backpack electroshocker to drive fish out of cover and corral them into nets, or caught fish by hook and line. Captured fish were quickly placed in bags of fresh river water to adjust for three to five minutes. A single individual (or 10-20 individuals of species $<0.5 \mathrm{~g}$ wet mass) was transferred into a new bag of filtered (Type A/E; Pall-Gelman, Ann Arbor, Michigan, USA) river water ( $1 \mathrm{~L})$ to incubate for $\sim 60$ minutes. For individuals $>50 \mathrm{~g}$ wet mass, we used shorter incubations (15 min) and larger volumes $(3 \mathrm{~L})$ to avoid oxygen stress and waste buildup. Despite our careful efforts to minimize handling and other stresses, it is possible that stress responses affected nutrient excretion rates during these procedures. However, results from our field methods are comparable to excretion rates predicted by mass balance models 
developed for armored catfish at this site (Hood et al. 2005).

Excretion rates were calculated based on the difference in dissolved nutrient concentrations between identical bags incubated with and without fish. Fecal production was low during incubations but was not quantified, therefore leaching of fecal nutrients may have contributed to our estimates of excretion rates in some cases. Water samples were filtered in the field (Gelman A/E) and analyzed the same day for $\mathrm{NH}_{4}$ or frozen for later analysis of total dissolved $\mathrm{P}$ (hereafter $\mathrm{P})$. We focused on $\mathrm{NH}_{4}$ because it is the primary $\mathrm{N}$ compound excreted by freshwater fish and is readily bioavailable, but analysis of total dissolved $\mathrm{N}$ in a subset of samples indicated that organic compounds constituted an average of $15 \%$ of total excreted $\mathrm{N} . \mathrm{NH}_{4}$ (hereafter $\mathrm{N})$ was quantified by fluorometry; background fluorescence was negligible, and matrix effects were variable and generally $<20 \%$ (i.e., underestimating $\mathrm{N}$ excretion), so no correction factors were applied (see Taylor et al. 2007). P was quantified using the molybdate-blue method after high-temperature persulfate digestion.

The excretion data collected during 2004 were combined with results from our initial survey in 1998 (reported in Vanni et al. 2002). Our goal was to obtain eight or more measurements from every common species and to sample rarer species opportunistically. This target balanced intraspecific replication against breadth of coverage of this species-rich fauna. To ensure that results were commensurate between years, 14 of the species sampled in 1998 were resampled during 2004 (two or more measurements in each year). ANCOVA indicated no significant differences in excretion rates among years or year-size interactions after accounting for individual size, so all data were merged. In addition, we used $\mathrm{N}$ excretion data collected by the same methods in 1999 to increase our sample size for the dominant large-bodied species (Prochilodus mariae).

To avoid undue influence of outliers, we discarded measurements that differed $>10$-fold from expected excretion rates based on all other conspecifics. This criterion resulted in rejection of only five measurements (1.1\% of data), and seven or more measurements remained from each species for which outliers were omitted. The final data set comprised 458 measurements representing 47 species and three orders of magnitude variation in wet mass $(0.12-236.0 \mathrm{~g}$; Appendix A). Thirty-seven species were represented by seven or more measurements, and 10 species by four or fewer measurements.

Size scaling of $\mathrm{N}$ and $\mathrm{P}$ excretion was described using ordinary least-squares regression of $\log _{10}$-transformed excretion rates against $\log _{10}$-transformed wet mass. Scaling patterns were analyzed both across the entire data set and for each species individually. ANCOVA was used to test for interspecific differences among wellsampled $(n \geq 7)$ species in $\log _{10}$-transformed excretion rates and excreted N:P ratio after accounting for size (using $\log _{10}$-transformed mass as a covariate).

Species-specific equations for the size scaling of $\mathrm{N}$ excretion were significant for 27 species, which together represented $61.9 \%$ of individual fish in the reach. For each of these species, we estimated per capita $\mathrm{N}$ excretion as the mean of the rates predicted from applying its scaling equation to the sizes of every individual weighed in 2004 ( $n=14-653$ per species). For species whose scaling equation for $\mathrm{N}$ excretion was not significant (20 species; $35.5 \%$ of fish in the reach), the per capita excretion rate was estimated as the mean of our species-specific measurements. Excretion rates were not measured in the remaining 22 species recorded in the reach, which represented $2.6 \%$ of fish. For these species, we applied scaling equations derived from the most closely related group represented in the data set (in decreasing order of preference: genus, family, order, or all data; Appendices B and C) to species-specific mass data ( $n=1-21$ per species).

For all species, per capita $\mathrm{P}$ excretion was calculated as the product of estimated per capita $\mathrm{N}$ excretion times the ratio of mean observed $\mathrm{P}$ excretion to mean observed $\mathrm{N}$ excretion. We chose this approach rather than using scaling analyses of $\mathrm{P}$ excretion because the explanatory power of $\mathrm{P}$ equations was much lower than for $\mathrm{N}$ (Appendix A). Average per capita $\mathrm{N}$ and $\mathrm{P}$ excretion rates estimated by these methods were within the range measured for each species.

To quantify the density and spatial distribution of all 69 fish species observed at the site during JanuaryMarch 2004, a team of three trained observers surveyed a $2.64-\mathrm{km}$ reach. We prioritized surveying a large area rather than repeatedly sampling a smaller area because our experience in this system suggested high spatial heterogeneity in both the density and species richness of the fish community. Within the focal reach, visual assessments and measurements of flow rates were used to delineate 49 channel units, each of which was relatively uniform in width, lateral depth profile, and velocity. For each channel unit, we measured the length, width, depth profile, and mean water velocity in the thalweg at the longitudinal midpoint of the channel unit, as well as the area occupied by submerged grasses and woody debris. Units were categorized as either "riffles" or "runs" using operational definitions based upon a combination of water velocity (riffles $>12 \mathrm{~cm} / \mathrm{s}$ ), visible turbulence (present in riffles), and maximum depth (riffles $<20 \mathrm{~cm}$ ). These categories reflected broad differences in habitat characteristics, but each included a range of geomorphic conditions. In particular, the few pools present in the reach were lumped with runs for ease of presentation. One area $(0.38 \mathrm{~km}$ length $)$ in the middle of the reach was excluded because the channel split around an island, a tributary entered, and vehicles periodically forded the streambed.

The clear water conditions in Rio Las Marias made it possible to survey fish densities using a variety of 
methods, each appropriate for a subset of species or microhabitats. We used a combination of visual observations (above and below water), electroshocking, and seining to census each species (Appendix B). Each method was applied from the bottom to the top of the reach over one to two days, and methods were applied successively during an 11-day period (191 person-hours of sampling). Final density estimates were based upon results from one to three methods per species, each targeting a different habitat or microhabitat (Appendix C). These methods were more likely to underestimate (by overlooking cryptic or small fish) than overestimate (by double-counting) fish densities; therefore our survey offers minimum density estimates within individual stream channel units and across the entire reach.

Species-level nutrient excretion was calculated as the product of population density and per capita excretion rates. Summing across species yielded aggregate excretion rates of $\mathrm{N}$ and $\mathrm{P}$ for the entire fish assemblage, which were used to calculate the aggregate excreted N:P ratio. These calculations were performed separately for each channel unit and for the reach as a whole. We used the variation among units in aggregate excretion rates and $\mathrm{N}: \mathrm{P}$ to evaluate the potential for fish to create nutrient recycling hotspots along the stream.

To assess the role of habitat type in creating spatial variation, we compared fish community characteristics (species richness, density, individual mass, community biomass) and aggregate excretion (N, P, N:P) between riffles and runs using $t$ tests. Within each habitat type, we used forward stepwise multiple regression to compare the influence of water velocity, mean depth, maximum depth, and proportional area of submerged grasses and wood on fish biomass, aggregate $\mathrm{N}$ and $\mathrm{P}$ excretion rates, and excreted $\mathrm{N}: \mathrm{P}$ ratio. We were also interested in the relative contributions of each functional group of fish to nutrient recycling and whether this varied among habitats. Species were assigned to trophic groups (algivore, detritivore, invertivore, piscivore, generalized carnivore [consuming invertebrate and vertebrate animals], omnivore [consuming algae and invertebrates], herbivore [consuming seeds, fruits, and flowers], and mucus feeder) based on gut contents (Appendix C). Using data from each channel unit, we tested for differences in proportional contributions to aggregate $\mathrm{N}$ and $\mathrm{P}$ excretion among habitat types, trophic groups, and habitat-group interactions using split-plot ANOVA, where channel units were plots and trophic groups were subplots.

The potential ecosystem-level importance of nutrient excretion by fish was evaluated using ecosystem $\mathrm{N}$ uptake rates and ambient nutrient concentrations as benchmarks. Areal $\mathrm{N}$ uptake rates were measured during January-March 2004 using short-term, wholestream additions of $\mathrm{NH}_{4}$ or $\mathrm{NO}_{3}$. Uptake rates were calculated from the longitudinal decline in $\mathrm{N}$ that was added to the stream to enhance ambient concentrations along a $0.5-1.0 \mathrm{~km}$ reach and were corrected for hydrological exchange following standard methods (Stream Solute Workshop 1990, Mulholland et al. 2002). In this paper we present only a summary of $\mathrm{N}$ uptake rates for comparison to excretion rates; these data will be presented in complete form elsewhere (A. Flecker, R. Hall, B. Taylor, S. Thomas, and A. Ulseth, unpublished data). We treat the mean uptake of $\mathrm{NH}_{4}$ as a minimum estimate of dissolved inorganic $\mathrm{N}$ (DIN) demand, and the sum of mean uptake of $\mathrm{NH}_{4}$ and $\mathrm{NO}_{3}$ measured in separate additions as a liberal estimate because it includes both assimilatory and nonassimilatory (nitrification, denitrification) demand for DIN.

To compare fish excretion to ambient nutrient concentrations, we converted areal excretion rates $\left(E_{\mathrm{A}}\right.$; mol nutrient $\left.\cdot \mathrm{m}^{-2} \cdot \mathrm{h}^{-1}\right)$ to volumetric units $\left(E_{\mathrm{V}} ; \mathrm{mol}\right.$ nutrient/L). Volumetric excretion rates integrated data on substrate area $(A$ : length $\times$ width), volume $(V$ : length $\times$ cross-sectional area) and travel time ( $T$ : length/water velocity) of each channel unit: $E_{\mathrm{V}}=\left(E_{\mathrm{A}} \times A \times T\right) / V . E_{\mathrm{V}}$ describes the average addition of dissolved nutrients (mol nutrient/L) by fish excretion as water flows through a unit, assuming complete mixing and no uptake.

Data on excretion rates, fish community characteristics, and habitat characteristics were $\log _{10}$-transformed prior to analysis. Proportions were arcsine square-root transformed. Post hoc comparisons were made using Tukey's hsd tests. Regressions, $t$ tests, and ANCOVA were performed using SYSTAT (SPSS, Chicago, Illinois, USA), and split-plot ANOVA was performed using SAS (Proc Mixed; SAS Institute, Cary, North Carolina, USA).

\section{Results}

Measured excretion rates per fish ranged from 0.22 to $575.35 \mu \mathrm{mol} \mathrm{N} / \mathrm{h}$ and from 0.01 to $75.14 \mu \mathrm{mol} \mathrm{P} / \mathrm{h}$ and showed allometric size scaling across the entire data set (Fig. 1). Scaling exponents were $0.923 \pm 0.016( \pm \mathrm{SE})$ for $\mathrm{N}(P<0.001)$ and $0.592 \pm 0.032$ for $\mathrm{P}(P<0.001)$ and described $88 \%$ and $43 \%$ of the variance, respectively. The positive scaling exponent of excreted N:P (0.329 \pm $0.029)$ indicated that larger fish excreted disproportionately more $\mathrm{N}$ than $\mathrm{P}(P<0.001)$, though mass explained only $22 \%$ of the variance.

After accounting for the effect of body mass, ANCOVA indicated significant differences among species in $\mathrm{N}$ excretion $\left(F_{36,365}=5.12 ; P<0.001\right)$ but no significant species-mass interaction $\left(F_{36,365}=0.97 ; P<\right.$ 0.527). For $\mathrm{P}$ excretion, both interspecific differences $\left(F_{36,356}=3.78 ; \quad P<0.001\right)$ and the species-mass interaction $\left(F_{36,356}=1.74 ; P=0.007\right)$ were significant. These patterns indicate that scaling exponents differed among species for $\mathrm{P}$ but not $\mathrm{N}$, and scaling coefficients were species-specific for both nutrients. Differential scaling of $\mathrm{N}$ and $\mathrm{P}$ excretion gave rise to a broad range of excreted N:P ratios (6-176 among species with $n \geq 8)$; both species identity $\left(F_{36,356}=2.86 ; P<0.001\right)$ and species-mass interactions $\left(F_{36,356}=1.89 ; P=0.002\right)$ had significant effects on N:P. 
At the species level, equations describing size scaling of $\mathrm{N}$ excretion rates were statistically significant for 27 species, and scaling equations for $\mathrm{P}$ excretion were significant for 12 species (Appendix A). Species-specific scaling exponents were generally similar to the crossspecies pattern for $\mathrm{N}$ excretion, but $\mathrm{P}$ scaling exponents varied widely among species, and explanatory power was low. For species in which excretion rates were not measured, scaling equations for $\mathrm{N}$ excretion generated for families, orders, or the whole data set were statistically significant (Appendix D). Among the 69 species recorded in the reach, estimated per capita excretion rates ranged from 0.05 to $499.24 \mu \mathrm{mol} / \mathrm{h}$ for $\mathrm{N}$ and from 0.004 to $21.309 \mu \mathrm{mol} / \mathrm{h}$ for $\mathrm{P}$.

The fish census yielded an estimate of 344589 individuals representing 69 species within the reach $(2.64 \mathrm{~km} ; 3.11 \mathrm{ha})$. The overall density and biomass of fish were $11.1 \mathrm{fish} / \mathrm{m}^{2}$ and $44.2 \mathrm{~g} / \mathrm{m}^{2}$, respectively, but fish were unevenly distributed across stream channel units (Fig. 2). Densities in riffles were significantly higher than in runs (mean \pm SE: $27.5 \pm 2.9$ vs. $5.1 \pm 0.8$ fish $\left./ \mathrm{m}^{2} ; t_{47}=10.27 ; P<0.001\right)$. However, more species were found in runs than riffles (mean \pm SE: $22.1 \pm 1.3$ vs. $\left.16.9 \pm 0.9 ; t_{47}=-3.32 ; P=0.002\right)$, and mean fish size was larger in runs (mean \pm SE: $11.0 \pm 2.6$ vs. $1.8 \pm 0.1$ $\left.\mathrm{g} ; t_{47}=-6.28 ; P<0.001\right)$. Contrasting patterns of individual size and population density balanced against each other to yield no significant differences in community biomass between riffles and runs (mean \pm SE: $46.2 \pm 4.6$ vs. $47.0 \pm 10.4 \mathrm{~g} / \mathrm{m}^{2} ; t_{47}=1.53 ; P=$ $0.134)$.

Combining per capita excretion rates and population density estimates for all species indicated aggregate excretion of $97.5 \mu \mathrm{mol} \mathrm{N} \cdot \mathrm{m}^{-2} \cdot \mathrm{h}^{-1}$ and $3.1 \mu \mathrm{mol}$ $\mathrm{P} \cdot \mathrm{m}^{-2} \cdot \mathrm{h}^{-1}$ across the entire reach (molar $\mathrm{N}: \mathrm{P}=31.3$ ). Due to heterogeneous distributions of fish biomass and community composition, aggregate areal excretion rates differed widely among channel units (Fig. 2). Aggregate $\mathrm{N}$ and $\mathrm{P}$ excretion rates were positively correlated across units $(r=0.71, n=49 ; P<0.001)$, but considerable variation remained. This partial decoupling of $\mathrm{N}$ and $\mathrm{P}$ excretion resulted in substantial spatial variation in aggregate excreted N:P (range 11.2 to 65.7 molar ratio; Fig. 2).

Aggregate $\mathrm{P}$ excretion rates were higher in riffles than runs (mean \pm SE: $4.7 \pm 0.4$ vs. $2.6 \pm 0.4 \mu \mathrm{mol}$ $\left.\mathrm{P} \cdot \mathrm{m}^{-2} \cdot \mathrm{h}^{-1} ; t_{47}=3.97 ; P<0.001\right)$, but average $\mathrm{N}$ excretion rates were equivalent between habitat types (mean \pm SE: $98.3 \pm 8.3$ vs. $94.7 \pm 19.9 \mu \mathrm{mol}$ $\mathrm{N} \cdot \mathrm{m}^{-2} \cdot \mathrm{h}^{-1}$ ). In fact, riffle fish contributed $45 \%$ of aggregate $\mathrm{P}$ excretion despite occupying $32 \%$ of the substrate area in the reach, whereas $\mathrm{N}$ excretion by riffle fish $(30 \%$ of total) was proportional to riffle area. Thus aggregate excreted $\mathrm{N}: \mathrm{P}$ was higher in runs than in riffles $\left(\right.$ mean \pm SE: $32.5 \pm 2.6$ vs. $21.3 \pm 1.0 ; t_{47}=-3.46 ; P=$ $0.001)$.

Contributions to aggregate excretion varied widely among fish trophic groups, but also depended on habitat
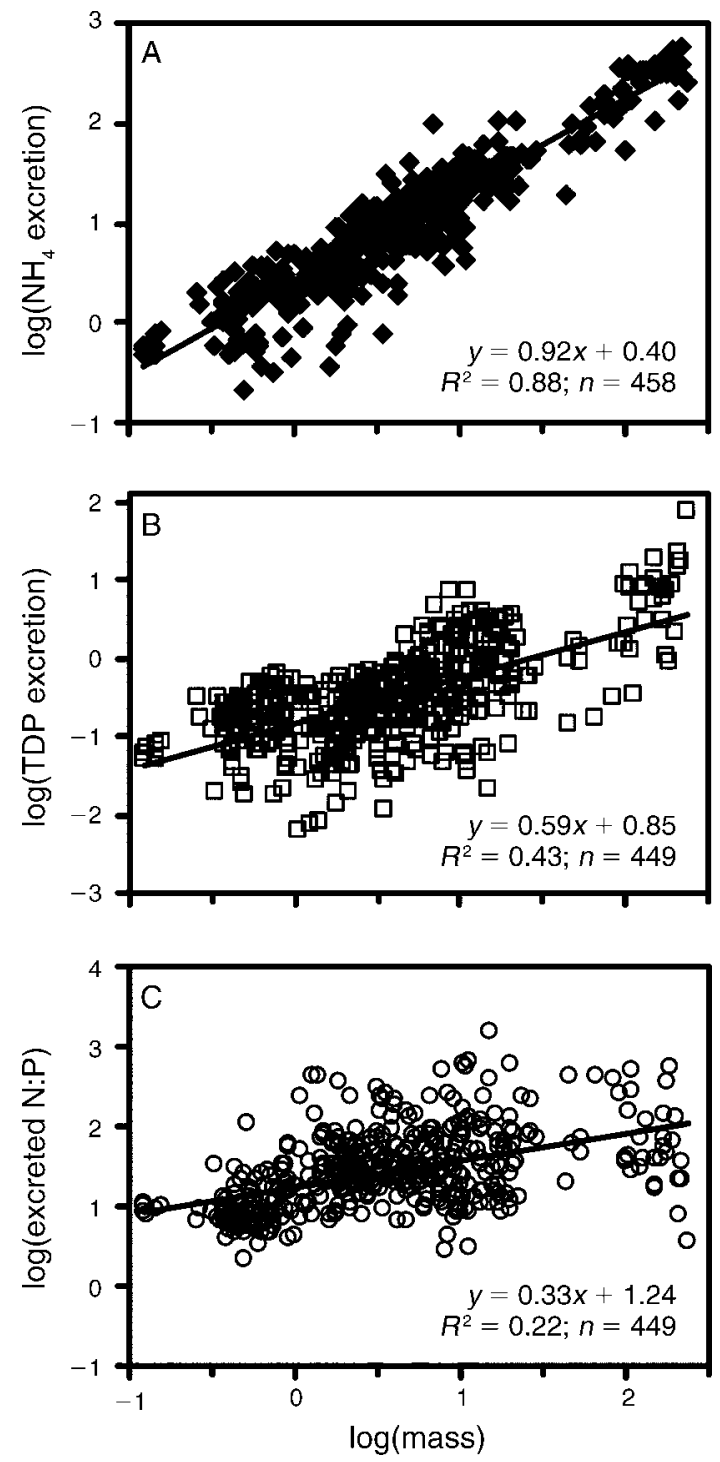

FIG. 1. Size scaling of (A) nitrogen and (B) phosphorus excretion rates, and $(\mathrm{C})$ excreted molar N:P ratio in 47 species of fish from Rio Las Marias, Venezuela. All data have been logtransformed: $\mathrm{NH}_{4}-\mathrm{N}$ was measured as $\mu \mathrm{mol} \mathrm{N} / \mathrm{h}$; total dissolved $\mathrm{P}$ was measured as $\mu \mathrm{mol} \mathrm{P} / \mathrm{h}$; mass was measured in grams. Each point represents a single measurement.

type for both $\mathrm{N}$ (trophic group-habitat type interaction, $\left.F_{7,329}=34.48 ; P<0.001\right)$ and $\mathrm{P}\left(F_{7,329}=42.09 ; P<\right.$ 0.001 ; Fig. 3). Across the entire reach, aggregate $\mathrm{N}$ excretion was dominated (47\% of total) by Prochilodus mariae, a large-bodied detritivore that was abundant in runs. Among channel units, pairwise comparisons indicated the following hierarchy in contributions to aggregate $\mathrm{N}$ excretion rates: detritivores in runs = algivores in riffles $>$ all remaining groups (based upon Tukey's hsd; $P \leq 0.05$ ). Contributions to $\mathrm{P}$ excretion followed a different pattern: omnivores in runs = algivores in riffles $=$ invertivores in riffles $>$ detritivores 


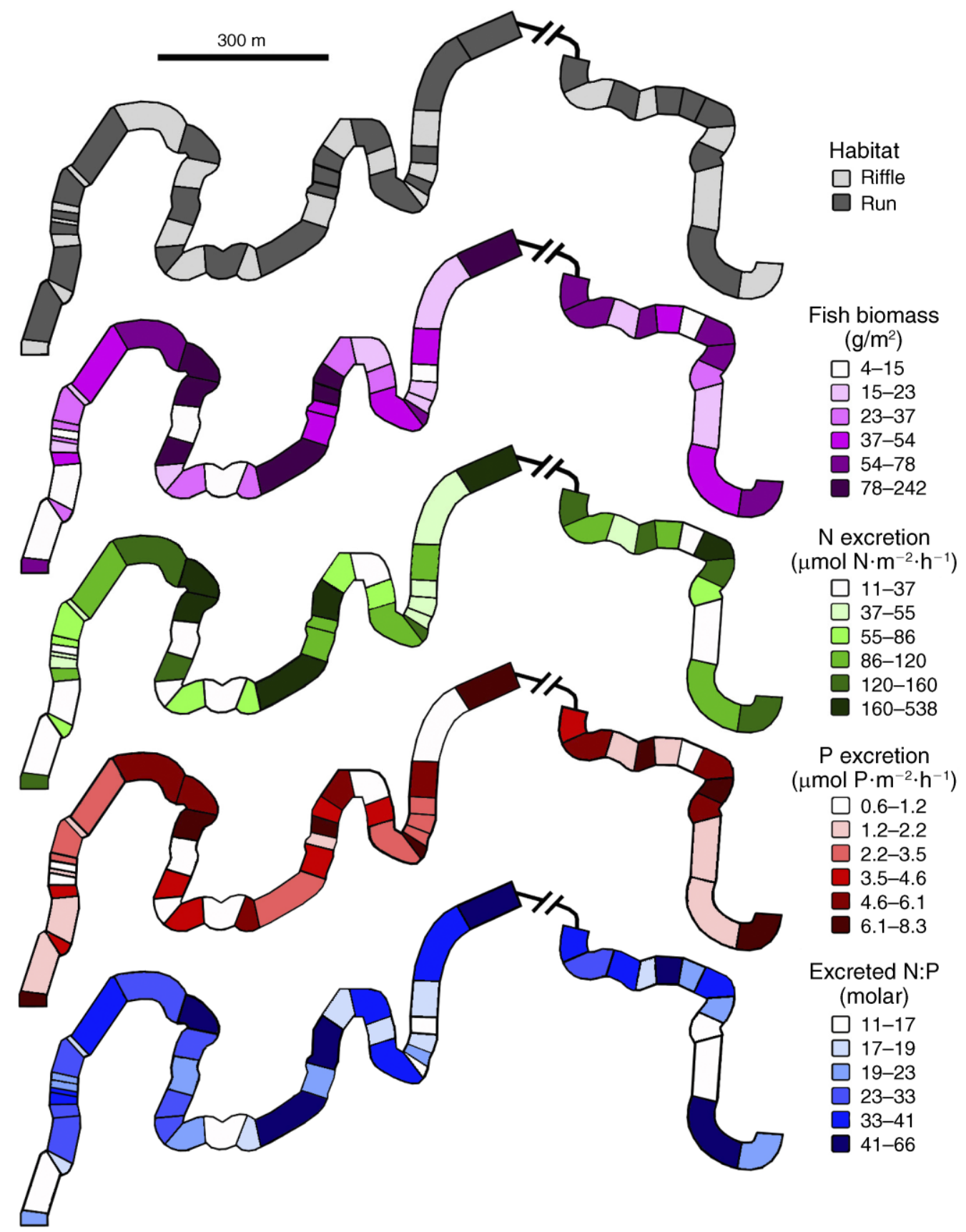

FIG. 2. Distribution of habitats, fish biomass, nutrient excretion rates for $\mathrm{N}$ and $\mathrm{P}$, and excreted molar N:P ratio along a $2.64-$ $\mathrm{km}$ reach of Rio Las Marias. The reach comprised 49 channel units, reflecting natural breaks between riffles and runs. Stream flow proceeds from right to left, and the broken line represents a $0.36-\mathrm{km}$ area that was not surveyed due to channel splitting and human disturbance.

in runs $=$ omnivores in riffles $>$ all remaining groups (Fig. 3).

Across all channel units, aggregate excretion rates were directly proportional to fish biomass for both $\mathrm{N}$ $\left(F_{1,47}=3100.87 ; P<0.001 ; R^{2}=0.995\right)$ and $\mathrm{P}\left(F_{1,47}=\right.$ $\left.101.11 ; P<0.001 ; R^{2}=0.676\right)$. However, the habitat characteristics that predicted fish biomass differed between runs and riffles. Water velocity was the only significant predictor of fish biomass in riffles $\left(t_{20}=2.83\right.$; $P=0.010)$, whereas maximum depth $\left(t_{23}=4.01 ; P=\right.$ $0.001)$ and the proportional area of submerged wood and grass $\left(t_{23}=2.08 ; P=0.049\right)$ were important in runs. The influence of habitat characteristics on aggregate nutrient excretion rates paralleled the patterns in fish biomass (Appendix E). Among runs, areal excretion rates of $\mathrm{N}\left(t_{23}=3.85 ; P=0.001\right)$ and $\mathrm{P}\left(t_{23}=2.54 ; P=\right.$ 

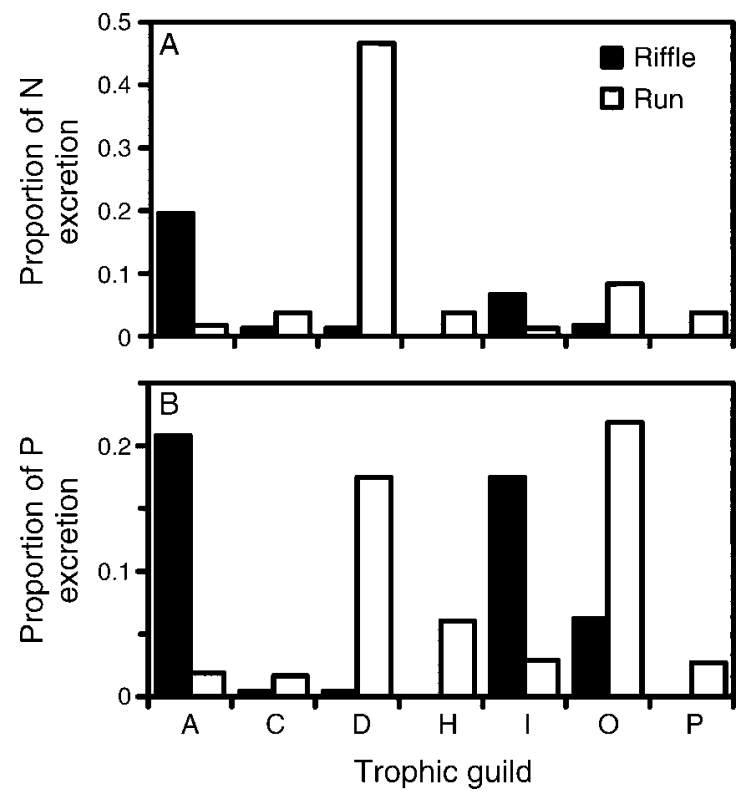

FIG. 3. Relative contributions to aggregate excretion of (A) nitrogen and (B) phosphorus as a function of fish trophic group and habitat type (riffle or run). Abbreviations are: A, algivore; $\mathrm{C}$, generalized carnivore; $\mathrm{D}$, detritivore; $\mathrm{H}$, herbivore; I, invertivore; $\mathrm{O}$, omnivore; and $\mathrm{P}$, piscivore. Bars in each panel sum to a total of 1.0 , and the negligible contribution of mucus suckers is not shown.

$0.018)$ were positively related to maximum depth, as was excreted N:P ratio $\left(t_{25}=8.30 ; P<0.001\right)$. Among riffles, water velocity was a significant predictor of $\mathrm{N}\left(t_{20}=\right.$ 2.64; $P=0.016)$ and $\mathrm{P}$ excretion $\left(t_{20}=2.33 ; P=0.031\right)$.

Comparing aggregate excretion to ecosystem $\mathrm{N}$ uptake suggests that fish were a potentially important source of dissolved inorganic N (DIN; Fig. 4). The areal rate of $\mathrm{N}$ excretion by fish throughout the reach $(97.5$ $\mu$ mol $\mathrm{N} \cdot \mathrm{m}^{-2} \cdot \mathrm{h}^{-1}$ ) exceeded mean $\mathrm{N}$ uptake observed during whole-stream additions of $\mathrm{NH}_{4}$ (mean $\pm \mathrm{SE}$ : $49.1 \pm 44.8 \mu \mathrm{mol} \mathrm{N} \cdot \mathrm{m}^{-2} \cdot \mathrm{h}^{-1} ; n=6$ ) or $\mathrm{NO}_{3}$ (mean $\pm \mathrm{SE}$ : $\left.80.5 \pm 50.7 \mu \mathrm{mol} \mathrm{N} \cdot \mathrm{m}^{-2} \cdot \mathrm{h}^{-1} ; n=5\right)$. Treating the sum of mean $\mathrm{NH}_{4}$ and $\mathrm{NO}_{3}$ uptake as a liberal estimate of demand, fish excretion could account for $>75 \%$ of DIN demand in the entire reach.

Expressing nutrient excretion in volumetric units indicates that fish could be an important source of dissolved $\mathrm{N}$ but not dissolved $\mathrm{P}$ (Fig. 5). Aggregate excretion rates averaged $330.8 \mathrm{nmol} \mathrm{N} \cdot \mathrm{L}^{-1} \cdot \mathrm{h}^{-1}$ and 10.5 $\mathrm{nmol} \mathrm{P} \cdot \mathrm{L}^{-1} \cdot \mathrm{h}^{-1}$. When standardized by the travel time of water through the entire reach $(\sim 11.8 \mathrm{~h})$, mean volumetric excretion rates $\left(E_{\mathrm{V}}\right)$ were sufficient to completely turn over the ambient $\mathrm{NH}_{4}$ pool $(<0.4 \mu \mathrm{mol}$ $\mathrm{N} / \mathrm{L}$ ) over a distance of $<0.3 \mathrm{~km}$, or more than eight times over the length of the reach. In contrast, $\mathrm{P}$ excretion was low relative to ambient total dissolved $\mathrm{P}$ $(0.30-0.42 \mu \mathrm{mol} \mathrm{P} / \mathrm{L})$; a distance of $>6 \mathrm{~km}$ would be required for complete $\mathrm{P}$ turnover.

The extreme spatial variation in aggregate nutrient excretion rates suggests that fish distributions created hotspots of nutrient regeneration within the reach (Fig. 2). Among channel units, $\mathrm{N}$ excretion ranged between $23 \%$ and $1094 \%$ of mean $\mathrm{NH}_{4}-\mathrm{N}$ uptake rates ( $>100 \%$ in 35 of 49 units) and between $9 \%$ and $415 \%$ of estimated DIN demand ( $>100 \%$ in 14 of 49 units). Runs exhibited both the highest and lowest ratios of $\mathrm{N}$ excretion to $\mathrm{NH}_{4}$ uptake rates $(\mathrm{CV}=1.13)$, whereas riffles varied much less $(\mathrm{CV}=0.40$; Fig. 4). Volumetric estimates of nutrient recycling by fish were even more variable. After standardizing for travel time, excretion $\left(E_{\mathrm{V}}\right)$ in each channel unit ranged from 4.4 to $591.8 \mathrm{nmol}$ $\mathrm{N} / \mathrm{L}$ and from 0.2 to $12.8 \mathrm{nmol} \mathrm{P} / \mathrm{L}$, corresponding to 134-fold and 85-fold variation, respectively.

\section{DisCUSSION}

Our survey revealed the broadest range of nutrient excretion rates and $\mathrm{N}: \mathrm{P}$ ratios reported from animals in a single ecosystem. This functional diversity reflects the large number of species and wide variety of trophic strategies, body sizes, and body nutrient contents represented among fish in Rio Las Marias. Ecological stoichiometry theory predicts that excretion rates are a function of the nutrient content of food resources and body tissues (Sterner and Elser 2002), and our initial

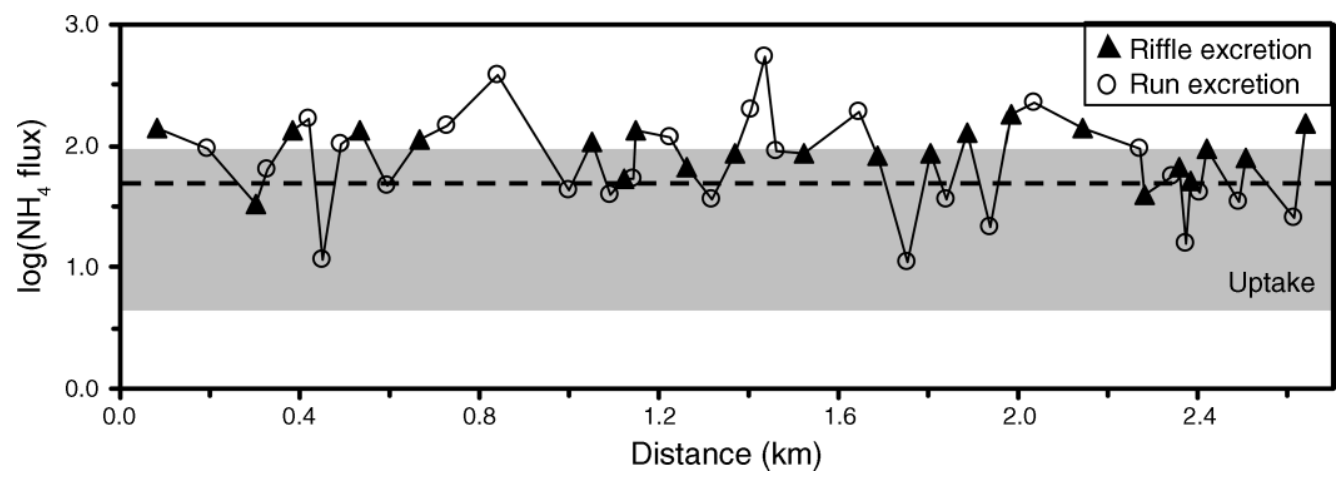

FIG. 4. Log-transformed areal $\mathrm{NH}_{4}$ excretion rates (originally measured as $\mu \mathrm{mol} \mathrm{N} \cdot \mathrm{m}^{-2} \cdot \mathrm{h}^{-1}$ ) of fish along the focal reach relative to ecosystem $\mathrm{NH}_{4}$ uptake. Markers indicate the sequence of riffle (triangles) and run (circles) channel units. Ecosystem $\mathrm{NH}_{4}$ uptake measurements $(n=6)$ are shown as the mean (dashed line) \pm SD (gray box). 

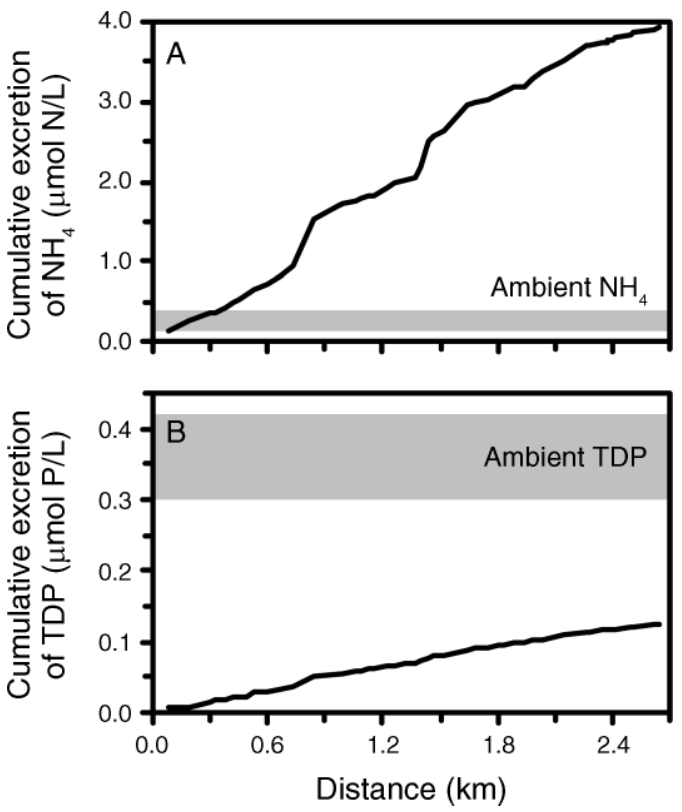

FIG. 5. Volumetric excretion of (A) $\mathrm{NH}_{4}$ and (B) total dissolved $\mathrm{P}$ (TDP) by fish. Lines indicate cumulative excretion during downstream flow and account for residence time in each channel unit. Gray boxes indicate the range of ambient concentrations observed in 2004 during the study.

work in this system indicated a strong correlation between excretion rates and body $\mathrm{P}$ content (Vanni et al. 2002). Broadening our coverage of the fauna in terms of phylogeny (synbranchid eels, gymnotiform knifefish), trophic groups (piscivores, terrestrial herbivores), and body size substantially expanded the range of excretion rates and N:P observed (Fig. 1).

The mechanistic basis for these interspecific differences is beyond the scope of this paper, but they clearly enhance the potential for heterogeneous fish distributions to create spatial variation in nutrient recycling. Moreover, the difference in size scaling of $\mathrm{N}$ and $\mathrm{P}$ recycling across the whole data set indicates that patterns of fish body size can influence aggregate excretion rates as much as the taxonomic structure of the community (see also Hall et al. 2007). For example, a 10 -fold change in excreted N:P could arise from either a mean size shift of three orders of magnitude or a taxonomic shift between like-sized species with low and high $\mathrm{P}$ excretion rates (Fig. 1).

Contemporaneous estimates of per capita excretion rates and population densities enabled us to calculate aggregate nutrient excretion with high taxonomic and spatial resolution (Fig. 2). The data used in both components of these calculations appear reasonable. The general validity of our excretion rate estimates is supported by their match to expectations from detailed mass balance models for armored catfish at the site (Hood et al. 2005), the overall similarity between our field results and predictions from coupled bioenergeticmass balance models for freshwater fish (Schindler and
Eby 1997), and the parity in results from conspecifics collected at various times and locations using multiple different methods. Our fish density estimates are conservative because they reflect only individuals that we observed or captured, and some secretive taxa were certainly underestimated (e.g., gymnotiforms, Synbranchus). However, the resulting biomass and density estimates are comparable to previous results from Rio Las Marias (Taylor et al. 2006) and another stream in the Venezuelan piedmont (Winemiller 1996).

Our calculations indicate that aggregate $\mathrm{N}$ excretion by fish constituted a large flux relative to both ecosystem $\mathrm{N}$ demand and ambient concentrations of $\mathrm{NH}_{4} . \mathrm{N}$ recycling rates exceeded average ecosystem $\mathrm{NH}_{4}$ uptake rates and could account for roughly $75 \%$ of dissolved inorganic N (DIN) uptake (Fig. 4). Our DIN benchmark may overestimate demand due to double-counting of uptake by organisms that use both $\mathrm{NH}_{4}$ and $\mathrm{NO}_{3}$ and inclusion of nonassimilatory $\mathrm{N}$ transformations (nitrification of $\mathrm{NH}_{4}$, denitrification of $\mathrm{NO}_{3}$ ), so $\mathrm{N}$ excretion by fish might meet $>75 \%$ of DIN demand. Aggregate excretion rates were equally impressive when expressed in terms of volumetric nutrient loading. Fish could have turned over the entire $\mathrm{NH}_{4}$ pool in a distance of $<0.3$ $\mathrm{km}$ in 2004 (Fig. 5), and even the highest ambient $\mathrm{NH}_{4}$ concentrations reported from Rio Las Marias in recent years $(\sim 1.1 \mu \mathrm{mol} \mathrm{N} / \mathrm{L}$; Taylor et al. 2007$)$ correspond to a turnover distance of $<1 \mathrm{~km}$.

Though our results suggest that nutrient mineralization by fish contributes substantially to meeting the $\mathrm{N}$ demands of algae and microbes, this inference must be interpreted cautiously for several reasons. Our calculations assume that excreted nutrients are mixed evenly into the water column, but this might not be true. For instance, nutrients excreted by fish residing upon or under the substrate could be retained by epilithon or enter hyporheic flow paths. Such local processes are poorly represented by whole-stream measurements of uptake rate or concentrations. In addition, short-term nutrient additions are prone to underestimating $\mathrm{N}$ uptake rates (Mulholland et al. 2002). However, this potential bias was minimized by elevating concentrations by $<1.7 \mu \mathrm{mol} \mathrm{N} / \mathrm{L}$ (two to five times ambient DIN), and the resulting uptake rates are within the range indicated by ${ }^{15} \mathrm{NH}_{4}$ additions (B. W. Taylor, unpublished data).

The apparent importance of nutrient recycling by fish has interesting implications for the supply: demand ratio for $\mathrm{N}$ vs. $\mathrm{P}$. The ambient availability of $\mathrm{P}$ in Rio Las Marias is high relative to $\mathrm{N}$ (Flecker et al. 2002), presumably due to mineral weathering in the nearby Andes mountains. As a consequence, we estimate that $\mathrm{P}$ excretion by fish turns over less than half of the dissolved $\mathrm{P}$ within our focal reach, whereas the $\mathrm{NH}_{4}$ pool may turn over eight times or more (Fig. 5). Moreover, the high N:P of aggregate fish excretion (29.9 molar) could compensate for the low $\mathrm{N}: \mathrm{P}$ of ambient dissolved nutrients $(<16$; Flecker et al. 2002) relative to 
periphyton $\mathrm{N}: \mathrm{P}(26.2 \pm 3.0$ [SD]; $n=6)$. Interestingly, primary consumers dominated $\mathrm{N}$ recycling in both riffles and runs, creating the potential for rapid cycling of this limiting nutrient between the water, periphyton, and consumers. Grazing fish also enhance algal responses to $\mathrm{N}$ additions (Flecker et al. 2002), suggesting synergies between fish effects on nutrient availability and demand.

Our results from Rio Las Marias add to evidence from tropical lakes (e.g., Andre et al. 2003) and coral reefs (e.g., Meyer et al. 1983) suggesting that excretion by fish can constitute an ecologically significant flux of $\mathrm{N}$ and $\mathrm{P}$. These cases all share a combination of low ambient nutrient concentrations, low anthropogenic nutrient loading, high nutrient demand by primary producers and microbes, and abundant fishes exhibiting a wide array of trophic strategies. This set of conditions is neither unique to nor ubiquitous within the tropics, but many tropical aquatic ecosystems feature tight coupling between primary productivity and nutrient recycling (Lewis 1987) as well as fish acting as both primary and higher-level consumers (Lowe-McConnell 1987). These factors undoubtedly enhance the importance of nutrient recycling by fish. However, fish densities in Rio Las Marias and another Venezuelan piedmont stream (Winemiller 1996) appear to be higher than in many other Neotropical and temperate streams (e.g., Angermeier and Karr 1983, Bojsen and Barraga 2002, Knouft 2002), so fish excretion may be less important elsewhere. In addition, our research was conducted exclusively during the dry season, which is a critical period for autochthonous productivity due to high transparency and lack of scouring spates. Low river discharge, the concentration of animal populations in the main channel, and the presence of migratory species are all likely to increase the importance of fish in nutrient cycling and other ecosystem processes during the dry season relative to the high-water conditions of the wet season (e.g., Winemiller et al. 2006).

Spatial hotspots of nutrient recycling.-Our results indicate that heterogeneous fish distributions create spatial hotspots of nutrient recycling in Rio Las Marias (Figs. 2 and 5). The 47-fold range among runs in aggregate $\mathrm{N}$ excretion rates was particularly striking. Moreover, the partial decoupling between $\mathrm{N}$ and $\mathrm{P}$ recycling rates of individual species resulted in a remarkable range of aggregate excreted N:P (11.2-65.7 molar; Fig. 2) that spanned the N:P of periphyton at the site (26.2 molar). Such differences in excreted N:P could mediate the relative supply of $\mathrm{N}$ and $\mathrm{P}$ to primary producers (e.g., Elser et al. 1988, Evans-White and Lamberti 2005), alleviating or enhancing $\mathrm{N}$ limitation. However, the actual influence of differences among channel units in excretion rates and $\mathrm{N}: \mathrm{P}$ would be attenuated by the averaging effect of downstream flow.

Several factors suggest that the inferred spatial variation in nutrient recycling reflects real, predictable patterns of fish distributions rather than sampling error. Most importantly, fish biomass and aggregate excretion were significantly associated with specific habitat characteristics within stream channel units (Appendix E), indicating that spatial variation is nonrandomly distributed. Moreover, the degree of error in fish densities that would be required to produce the broad range of aggregate excretion rates among channel units is unlikely. For example, the difference between the highest and lowest unit-scale $\mathrm{N}$ excretion rates corresponds to overlooking 1819 large-bodied Prochilodus mariae or 220186 small-bodied Bryconamericus cismontanus in a single shallow run. Spatial variation in aggregate excretion rates could be exaggerated if individual excretion rates or body size differ consistently among units, which could occur if competition for food resources generates density-dependent feeding or growth rates. Though we cannot exclude that possibility, the similarity in size-specific excretion rates among fish collected in different channel units and years suggests limited intraspecific variability.

The implications of spatial variation in nutrient recycling for ecosystem functioning depend on the temporal stability of fish distributions (Hall et al. 2007). Our field experience suggests that major patterns of fish distributions are stable during the dry season despite movement by individual fish during the day and night (see also Matthews et al. 1994, Winemiller 1996). For example, Prochilodus mariae and other large species move within and between channel units to feed, yet their densities are consistently highest in a small subset of units. Similarly, many smaller species are habitat specialists that congregate in preferred areas unless forced to move by desiccation or flooding (Power 1984b, Winemiller 1996). Thus spatial variation in fish densities are probably stable enough to create nutrient recycling hotspots during the dry season.

The short generation times of algae and microbes allow them to respond to nutrient availability on time scales of hours to days, but sustained spatial variation in recycling could have even stronger effects by creating feedbacks between the distribution of dissolved nutrients, primary producers, and heterotrophs. For instance, channel units with high fish excretion rates might become hotspots of primary productivity and microbial activity, or conversely the most productive channel units might attract the highest densities of fish (e.g., Power 1984b). Our present results, and previous evidence that fish create patchy distributions of $\mathrm{N}$-fixing cyanobacteria (Flecker 1996, Flecker and Taylor 2004), indicate that such spatial associations between fish distributions and ecosystem processes are likely in Rio Las Marias.

Variation in aggregate nutrient excretion among channel units could be produced by patterns in total biomass, size distribution, or phylogenetic composition of fish communities. Given the strength of phylogenetic influence on excretion rates in Rio Las Marias (Vanni et al. 2002), we had expected that differences in aggregate excretion among units would reflect the distribution of fish families with low (e.g., characid 
tetras) or high (e.g., loricariid armored catfish) excreted $\mathrm{N}: \mathrm{P}$. The fish survey indicated that riffles are dominated by algivorous armored catfishes (e.g., Ancistrus triradiatus and Chaetostoma milesi) and characins (i.e., Parodon apolinari), as well as insectivorous catfishes (e.g., Cetopsorhamdia rosei) and darters (e.g., Characidium boavistae). In runs, omnivorous tetras (e.g., Bryconamericus cismontanus) and detritivorous Prochilodus mariae were dominant (Fig. 3). These distribution patterns would predict high excreted N:P in riffles due to armored catfish and low N:P in runs due to the abundance of tetras. To the contrary, we estimated higher aggregate excreted $\mathrm{N}: \mathrm{P}$ in runs than in riffles, suggesting that phylogenetic composition is not the primary explanation for spatial variation in excretion rates.

Associations between body size and habitat type offer a better explanation for differences in aggregate excretion between riffles and runs. Riffles were characterized by dense populations of small fish, whereas runs had lower densities but larger species. Size and density were roughly offsetting in terms of total biomass and aggregate $\mathrm{N}$ excretion, but steeper size scaling of $\mathrm{N}$ than $\mathrm{P}$ excretion (Fig. 1) gave rise to higher aggregate $\mathrm{P}$ excretion rates and lower $\mathrm{N}: \mathrm{P}$ in riffles (Fig. 2). Moreover, despite greater interspecific variation in excretion rates of $\mathrm{P}$ than $\mathrm{N}$ (Fig. 1; Vanni et al. 2002), aggregate $\mathrm{N}$ excretion was considerably more variable across channel units than aggregate $\mathrm{P}$ excretion $(\mathrm{CV}$, 0.89 vs. 0.60 ; Fig. 2 ). These patterns suggest that the size structure of fish communities is a key influence on their aggregate excretion rates and N:P.

Within each habitat type, the substantial variation in aggregate excretion reflected the influence of habitat characteristics on fish biomass. In riffles, fish biomass increased with water velocity because faster-flowing channel units had higher fish densities $(r=0.60, n=22$; $P=0.003)$ rather than larger fish $(r=0.14, n=22 ; P=$ 0.536). In contrast, the importance of depth in runs reflected variation in the abundance of large fish $(>100$ g), which contributed $>75 \%$ of $\mathrm{N}$ excretion in runs deeper than $30 \mathrm{~cm}$. The uneven distribution of large fish in runs was responsible for both the lowest and highest aggregate excretion rates in the reach, whereas hotspots rarely occurred in riffles (Fig. 4). The detritivore Prochilodus mariae was an especially dominant influence (McIntyre et al. 2007), and its preference for deep runs could reflect greater availability of its food source (sediment) there. Alternatively, many fish use deep areas to evade predators (Angermeier and Karr 1983, Power 1984a, Schlosser 1987), and our field observations suggest that Prochilodus and other large fish in Rio Las Marias seek refuge from fishermen in deep runs. In any case, our results highlight the potential to merge habitat mapping with data on the functional roles of animal species to predict spatial variation in ecosystem processes.

Conclusions.-There is growing appreciation of the importance of biogeochemical hotspots in ecosystems, particularly where chemical or physical boundaries facilitate exchange of reactants (McClain et al. 2003). Recent conceptual models of the hierarchical physical structure and biogeochemistry of streams have incorporated small-scale hotspots of nutrient transformations (Fisher et al. 1998, Malard et al. 2002), primarily in the context of surface-subsurface hydrological exchanges (e.g., Dent and Grimm 1999, Dent et al. 2001, Lovell et al. 2001). Our work indicates that spatial variation in the density and composition of animal communities can also give rise to hotspots of nutrient recycling, and that species-specific attributes such as body size and habitat use may affect the location and magnitude of hotspots in predictable ways.

We suspect that fish and other animals often create hotspots of nutrient recycling in streams. It has become clear that stream animals can influence both nutrient demand (e.g., Steinman et al. 1995, Flecker et al. 2002) and nutrient recycling (e.g., Grimm 1988, Vanni et al. 2002, Hall et al. 2003). There is also abundant evidence that the distribution of fish and invertebrates in streams is patchy due to habitat preferences, species interactions, and social behaviors (Matthews 1998, Allan and Castillo 2007). Given that these two key requirements (ecosystem-level importance and spatial heterogeneity) are frequently met by stream animals, their role in generating and responding to biogeochemical hotspots merits further investigation.

\section{ACKNOWLEDGMENTS}

We thank B. Daley, R. Hall, Jr., A. Ulseth, and especially C. Rockwood and D. Lowry for help in the field. D. Taphorn and the Figueredo and Perez families provided critical assistance in Venezuela. We are grateful to M. Brown, A. Galford, L. Hedin, R. Howarth, and J. Headworth for laboratory assistance; to S. Ellner and F. Vermelyen for statistical advice; and to $\mathrm{N}$. Hairston, Jr., R. Hall, Jr., B. Peckarsky, D. E. Schindler, and two anonymous reviewers for helpful comments. Funding was provided by the NSF through a graduate fellowship, the IGERT in Biogeochemistry at Cornell (DGE-0221658), and research grants (DEB-9615349, DEB-9615620, DEB-0321471, INT-0321443).

\section{Literature Cited}

Allan, J. D., and M. M. Castillo. 2007. Stream ecology: structure and function of running waters. Second edition. Springer, New York, New York, USA.

Andre, E. R., R. E. Hecky, and H. C. Duthie. 2003. Nitrogen and phosphorus regeneration by cichlids in the littoral zone of Lake Malawi, Africa. Journal of Great Lakes Research 29S2:190-201.

Angermeier, P. L., and J. R. Karr. 1983. Fish communities along environmental gradients in a system of tropical streams. Environmental Biology of Fishes 9:117-135.

Attayde, J. L., and L. Hansson. 2001. Fish-mediated nutrient recycling and the trophic cascade in lakes. Canadian Journal of Fisheries and Aquatic Sciences 58:1924-1931.

Bojsen, B. H., and R. Barraga. 2002. Effects of deforestation on fish community structure in Ecuadorian Amazon streams. Freshwater Biology 47:2246-2260.

Bracken, M. E. S. 2004. Invertebrate-mediated nutrient loading increases growth of an intertidal macroalga. Journal of Phycology 40:1032-1041. 
Caraco, N. F., and J. J. Cole. 2002. Contrasting impacts of a native and alien macrophyte on dissolved oxygen in a large river. Ecological Applications 12:1496-1509.

Dent, C. L., and N. B. Grimm. 1999. Spatial heterogeneity of stream water nutrient concentrations over successional time. Ecology 80:2283-2298.

Dent, C. L., N. B. Grimm, and S. G. Fisher. 2001. Multiscale effects of surface-subsurface exchange on stream water nutrient concentrations. Journal of the North American Benthological Society 20:162-181.

Elser, J. J., M. M. Elser, N. A. MacKay, and S. R. Carpenter. 1988. Zooplankton-mediated transitions between nitrogen and phosphorus limited algal growth. Limnology and Oceanography 33:1-14.

Evans-White, M. A., and G. A. Lamberti. 2005. Grazer species effects on epilithon nutrient composition. Freshwater Biology $50: 1853-1863$.

Fisher, S. G., N. B. Grimm, E. Marti, and R. Gomez. 1998. Hierarchy, spatial configuration, and nutrient cycling in a desert stream. Australian Journal of Ecology 23:41-52.

Flecker, A. S. 1996. Ecosystem engineering by a dominant detritivore in a diverse tropical stream. Ecology 77:18451854.

Flecker, A. S., and B. W. Taylor. 2004. Tropical fishes as biological bulldozers: density effects on resource heterogeneity and species diversity. Ecology 85:2267-2278.

Flecker, A. S., B. W. Taylor, E. S. Bernhardt, J. M. Hood, W. K. Cornwell, S. R. Cassatt, M. J. Vanni, and N. S. Altman. 2002. Interactions between herbivorous fishes and limiting nutrients in a tropical stream ecosystem. Ecology 83: 1831-1844.

Grimm, N. B. 1988. Role of macroinvertebrates in nitrogen dynamics of a desert stream. Ecology 69:1884-1893.

Hall, R. O., Jr., B. J. Koch, M. C. Marshall, B. W. Taylor, and L. M. Tronstad. 2007. How body size mediates the role of animals in nutrient cycling in aquatic ecosystems. Pages 286305 in A. G. Hildrew, R. Edmonds-Brown, and D. Raffaelli, editors. Body size: the structure and function of aquatic ecosystems. Cambridge University Press, New York, New York, USA.

Hall, R. O., Jr., J. L. Tank, and M. F. Dybdahl. 2003. Exotic snails dominate nitrogen and carbon cycling in a highly productive stream. Frontiers in Ecology and Environment 1: 407-411.

Helfield, J. M., and R. J. Naiman. 2001. Effects of salmonderived nitrogen on riparian forest growth and implications for stream productivity. Ecology 82:2403-2409.

Hood, J. M., M. J. Vanni, and A. S. Flecker. 2005. Nutrient recycling by two phosphorus-rich grazing catfish: potential for phosphorus limitation of fish growth. Oecologia 146:247257.

Hudson, J. J., W. D. Taylor, and D. W. Schindler. 1999. Planktonic nutrient regeneration and cycling efficiency in temperate lakes. Nature 400:659-661.

Knouft, J. H. 2002. Regional analysis of body size and population density in stream fish assemblages: testing predictions of the energetic equivalence rule. Canadian Journal of Fisheries and Aquatic Sciences 59:1350-1360.

Kraft, C. E. 1993. Phosphorus regeneration by Lake Michigan alewives in the mid-1970s. Transactions of the American Fisheries Society 122:749-755.

Lewis, W. M. 1987. Tropical limnology. Annual Review of Ecology and Systematics 18:159-184.

Lovell, B., I. D. McKelvie, and D. Nash. 2001. Sampling design for total and filterable reactive phosphorus monitoring in a lowland stream: consideration of spatial variability, measurement uncertainty and statistical power. Journal of Environmental Monitoring 3:463-468.

Lowe-McConnell, R. H. 1987. Ecological studies in tropical fish communities. Cambridge University Press, New York, New York, USA.
Malard, F., K. Tockner, M. Dole-Olivier, and J. Ward. 2002. A landscape perspective on surface-subsurface hydrological exchanges in river corridors. Freshwater Biology 47:621-640.

Matthews, W. J. 1998. Patterns in freshwater fish ecology. Chapman and Hall, New York, New York, USA.

Matthews, W. J., B. C. Harvey, and M. E. Power. 1994. Spatial and temporal patterns in the fish assemblages of individual pools in a Midwestern stream (U.S.A.). Environmental Biology of Fishes 39:381-397.

McClain, M. E., E. W. Boyer, C. L. Dent, S. E. Gergel, N. B. Grimm, P. M. Groffman, S. C. Hart, J. W. Harvey, C. A. Johnston, E. Mayorga, W. H. McDowell, and G. Pinay. 2003. Biogeochemical hot spots and hot moments at the interface of terrestrial and aquatic ecosystems. Ecosystems 6:301-312.

McIntyre, P. B., L. E. Jones, A. S. Flecker, and M. J. Vanni. 2007. Fish extinctions alter nutrient recycling in tropical freshwaters. Proceedings of the National Academy of Sciences (USA) 104:4461-4466.

Meyer, J. L., E. T. Schultz, and G. S. Helfman. 1983. Fish schools: an asset to corals. Science 220:1047-1049.

Mulholland, P. J., et al. 2002. Can uptake length in streams be determined by nutrient addition experiments? Results from an interbiome comparison study. Journal of the North American Benthological Society 21:544-560.

Naiman, R. J., S. R. Elliott, J. M. Helfield, and T. C. O'Keefe. 2000. Biophysical interactions and the structure and dynamics of riverine ecosystems: the importance of biotic feedbacks. Hydrobiologia 410:79-86.

Nakashima, B. S., and W. C. Leggett. 1980. The role of fishes in the regulation of phosphorus availability in lakes. Canadian Journal of Fisheries and Aquatic Sciences 37:1540-1549.

Power, M. E. 1984a. Depth distributions of armored catfish: predator-induced resource avoidance. Ecology 65:523-528.

Power, M. E. 1984b. Habitat quality and the distribution of algae grazing catfish in a Panamanian stream. Journal of Animal Ecology 53:357-374.

Schindler, D. E., and L. A. Eby. 1997. Stoichiometry of fishes and their prey: implications for nutrient recycling. Ecology 78:1816-1831.

Schindler, D. E., R. A. Knapp, and P. R. Leavitt. 2001. Alteration of nutrient and algal production resulting from fish introductions into mountain lakes. Ecosystems 4:308-321.

Schlosser, I. J. 1987. The role of predation in age-related and size-related habitat use by stream fishes. Ecology 68:651-659.

Steinman, A. D., P. J. Mulholland, and J. J. Beauchamp. 1995. Effects of biomass, light, and grazing on phosphorus cycling in stream periphyton communities. Journal of the North American Benthological Society 14:371-381.

Sterner, R. W., and J. J. Elser. 2002. Ecological stoichiometry: the biology of elements from molecules to the biosphere. Princeton University Press, Princeton, New Jersey, USA.

Stream Solute Workshop. 1990. Concepts and methods for assessing solute dynamics in stream ecosystems. Journal of the North American Benthological Society 9:95-119.

Taphorn, D. C. 1992. The characiform fishes of the Apure River drainage, Venezuela. Biollania Edicion Especial 4.

Taylor, B. W., A. S. Flecker, and R. O. Hall, Jr. 2006. Loss of a harvested fish species disrupts carbon flow in a diverse tropical river. Science 313:833-836.

Taylor, B. W., C. Keep, R. O. Hall, Jr., B. Koch, L. Tronstad, A. S. Flecker, and A. J. Ulseth. 2007. Improving the fluorometric ammonium method: matrix effects, background fluorescence, and standard additions. Journal of the North American Benthological Society 26:167-177.

Vanni, M. J. 2002. Nutrient cycling by animals in freshwater ecosystems. Annual Review of Ecology and Systematics 33: 341-370.

Vanni, M. J., A. S. Flecker, J. M. Hood, and J. L. Headworth. 2002. Stoichiometry of nutrient recycling by vertebrates in a tropical stream: linking species identity and ecosystem processes. Ecology Letters 5:285-293. 
Wetzel, R. G. 1990. Land-water interfaces: metabolic and limnological regulators. Verhandlungen Internationale Vereinigung für Theoretische und Angewandte Limnologie 24:6-24.

Winemiller, K. O. 1990. Spatial and temporal variation in tropical fish trophic networks. Ecological Monographs 60: 331-367.

Winemiller, K. O. 1996. Dynamic diversity in fish assemblages of tropical rivers. Pages 99-134 in M. L. Cody and J. A. Smallwood, editors. Long-term studies of vertebrate communities. Academic Press, San Diego, California, USA.
Winemiller, K. O., J. V. Montoya, D. L. Roelke, C. A. Layman, and J. B. Cotner. 2006. Seasonally varying impact of detritivorous fishes on the benthic ecology of a tropical floodplain river. Journal of the North American Benthological Society 25:250-262.

Wright, J. P., and A. S. Flecker. 2004. Deforesting the riverscape: the effects of wood on fish diversity in a Venezuelan piedmont stream. Biological Conservation 120: 443-451.

\section{APPENDIX A}

A table showing fish species for which nitrogen and phosphorus excretion were directly measured (Ecological Archives E089-132A1).

\section{APPENDIX B}

A description of fish census methods used in our study (Ecological Archives E089-132-A2).

\section{APPENDIX C}

A table showing a complete list of fish species included in the study, with indication of whether nutrient excretion was measured directly, the method for estimating per capita excretion, population density estimation method, and trophic guild designations (Ecological Archives E089-132-A3).

\section{APPENDIX D}

A table showing scaling equations used to estimate nitrogen excretion by species from which direct measurements were not available (Ecological Archives E089-132-A4).

\section{APPENDIX E}

A figure showing influence of habitat characteristics on aggregate nitrogen excretion by fishes (Ecological Archives E089-132-A5). 